\title{
Profile on childbirth care at a public maternity hospital
}

Maria Tainara dos Santos Resende 1

D https://orcid.org/0000-0002-6930-1309

Denise Semirames Lopes 2

D https://orcid.org/0000-0003-4253-3895

Elisiane Gomes Bonfim 3

https://orcid.org/0000-0003-2812-1704

1-3 Departamento de Enfermagem. Universidade Federal do Piauí. Campus Ministro Petrônio Portela, SG 12. Bairro Ininga. Teresina, PI, Brasil. CEP: 64.049-550. E-mail: tainara.resende@hotmail.com

\begin{abstract}
Objectives: to describe the profile on childbirth care at a reference maternity hospital in the State of Piaui based on the 2018 World Health Organization Recommendations.

Methods: retrospective cross-sectional quantitative study, descriptive documentary, population census, containing vaginal deliveries performed in 2017. The data was entered in Microsoft Excel for simple statistical analysis.

Results: the percentages registered at the Centro Obstétrico Superior (Superior Obstetric Center) and Centro de Parto Normal (Normal Delivery Center) were, respectively, $85.5 \%$ and $98 \%$ with the presence of a companion, $34.2 \%$ and $94 \%$ used the partogram, $63.8 \%$ and $98 \%$ took non-pharmacological methods for pain relief, $74.8 \%$ and $98.7 \%$ received fluids during labor. Amniotomy at $15.2 \%$ and $17.2 \%$, oxytocin was administered at $26.5 \%$ and $14.6 \%$ in the 1st and 2 nd periods, non-lithotomic position at $39.7 \%$ and $93.4 \%$, episiotomy $9.9 \%$ and $6.6 \%$. After birth, $85.5 \%$ and $96 \%$ of newborns had skin-to-skin contact and, in $65.5 \%$ and $94 \%$ there were maternal breastfeeding promotion.

Conclusions: this study comprehended the indicators on childbirth care service, which are, in general, better than the national and the northeast region ones. The importance of registering indicators to evaluate care is emphasized.
\end{abstract}

Key words Tocology, Normal delivery, World Health Organization, Quality indicators in healthcare 


\section{Introduction}

In the 1990s, discussions were held in several countries and research-based data resulted in the publication on Care in Normal Birth: A Practical Guide. Recommendations by the World Health Organization (WHO), sought to provide means to combat the high rates of maternal and neonatal mortality. This publication had a global impact and motivated numerous governments to adapt delivery care, seeking to reduce death rates from preventable causes. 1,2

The search for improvement in the quality of obstetric care in several countries motivated the debate on the cautious use of technologies in childbirth and birth care. After 22 years on the publication of the practical guide on recommendations by the World Health Organization on childbirth care, there was an update of the practices that should or should not be adopted in each of the four clinical periods of deliveries and for the newborn. These recommendations, published in 2018 , are based on scientific evidence, thus reinforcing their reliability. ${ }^{3}$

Brazil was one of the countries that sought to adapt this care and reduce the preventable deaths of women and newborns. In recent decades, the Ministry of Health has instituted a series of policies and programs focused on childbirth care: Programa de Assistência Integral à Saúde da Mulher (The Integral Care Program on Women's Health); Programa de Humanização no Pré-Natal e Nascimento (Prenatal and Birth Humanization Program); Política Nacional de Atenção Integral à Saúde da Mulher (National Policy for Integral Care on Women's Health). 4-6

Thus, the Rede Cegonha (Stork Network) emerged as a care network that aimed to guarantee women the right to reproductive planning and humanized care at pregnancy, at childbirth and for the puerperium, as well as to the child, the right to have a safe birth, healthy growth and development. 7,8

Humanization in the context of the Rede Cegonha (Stork Network) and the WHO Recommendations assume the conception of obstetric care that respects the physiology of childbirth and the woman's role in this process, through practices based on scientific evidence in order to deconstruct the technocratic model that values the use of unnecessary and harmful invasive conducts. ${ }^{7}$

A frequent element in the Brazilian obstetric practice is the rush to accelerate birth, without respecting women's autonomy in their childbirth experience. The control of time and the imposition of the dynamics of labor and childbirth explain the excessive rate of interventions, including unnecessary cesarean sections, and making chidlbirth care in the country focused on medical decision and not on the physiological process. ${ }^{9}$

Despite the efforts, research has shown that childbirth care is still very far from the recommended and is influenced by the biomedical model, in which the aspects such as women's autonomy during labor are not respected and harmful practices to maternal and neonatal's health usually occur. 10,11

The WHO recommendations define a set of interventions so that the delivery process is not only safe, but also has a positive experience for women and their families. By outlining a new model of childbirth care adaptable to the context of each country, the recommendations aim at substantial cost savings by reducing unnecessary interventions during labor. ${ }^{3}$

Considering this, one way to analyze the health situation of an individual or a given population in a quantified way and analyze the information collected is the use of instruments, such as health indicators. The analysis on health indicators enables the recognition and monitoring on the performance of the health system, besides contributing to a continuous improvement on access to care and quality on maternal and child health offered at a local and national level.12,13 Quality care associated with scientific evidence-based practice, is on the rise in the world panorama, requiring health services to improve healthcare, as well as the permanent analysis on their indicators.

This research is based on the following hypothesis: if care for women in labor at a public maternity hospital in the State of Piauí is in accordance with the recommendations by the World Health Organization. The study aims to describe the profile on childbirth care at a reference maternity hospital in the State of Piauí, based on the Recommendations of the World Health Organization.

\section{Methods}

This is a retrospective, descriptive and documentary cross-sectional quantitative study. Data collection occurred at a public maternity of tertiary care, a high-risk reference, in the State of Piauí.

The study population was census-designated, containing the universe of vaginal deliveries performed at the maternity from January to December 2017 that had a registration of the indicators. The study variables were from the WHO Recommendations published in 2018 on intrapartum care. 
The procedure for data collection included the request for access to vaginal delivery indicators, referring to the Centro Obstétrico Superior (COS) (Superior Obstetric Center) and the Centro de Parto Normal (CPN) (Normal Delivery Center). They are distinct because it is up to the first one to assist highrisk vaginal deliveries and the second, low-risk vaginal deliveries.

The service had the quantitive number of indicators available on childbirth care in electronic spreadsheets stored in the computers at of the Serviço de Arquivo Médico e Estatística (SAME) (Medical and Statistical Archive Service), registered under the name of the Childbirth Indicator Form. After having access, the data were included in its own form that contained the WHO Recommendations published in 2018.

Then, the data were inserted into Microsof Excel spreadsheets in order to perform the analysis on each indicator collected, relating the number of deliveries performed in each sector by descriptive statistics. This was performed by adding the values of each indicator and its percentages by using the following formula:

Indicator's Percentage $(\%)=(\Sigma$ of the indicator's values $\times 100) \div$ Total of childbirths at the sector in a year

The study was approved by the Ethics Committee of the Universidade Federal do Piauí, Document number: 2.948.617 and is in accordance with the determinations of Resolution n. 466/2012 of the National Health Council.14 No medical records or any documents identifying the parturient were accessed. Since this is a documentary research, the Terms of Commitment to Use Data (TCUD) to obtain access to the necessary documents for data collection was used.

\section{Results}

According to Table 1, the total number of deliveries registered at the Centro Obstétrico Superior (COS) (Superior Obstetric Center) was 2,853, and at the Centro de Parto Normal (CPN) (Normal Delivery Center), the quantity of deliveries their indicators registered was 151 (data from January to May 2017). There was no data information in the Serviço de Arquivo Médico e Estatística (SAME) (Medical and Statistical Archive Service) from June to December 2017. In relation to these totals, $85.5 \%$ of the deliveries at the Centro Obstétrico Superior (COS) (Superior Obstetric Center) had the presence of a companion or doula, while at the Centro de Parto Normal (CPN) (Normal Delivery Center) the percentage was $98 \%$.

At the Centro Obstétrico Superior (COS) (Superior Obstetric Center), the partogram was used at $34.2 \%$ of the deliveries. Most women $(63.8 \%)$ took non-pharmacological methods for pain relief and $74.8 \%$ received fluids during labor. The percentage of artificial rupture of the membranes was $15.2 \%$. Oxytocin was administered at $26.5 \%$ of the cases in the 1 st and 2 nd periods of delivery. Regarding to the deliveries performed at the Centro de Parto Normal (CPN) (Normal Delivery Center), $94 \%$ used the partogram, $98 \%$ of the women took non-pharmacological methods for pain relief and $98.7 \%$ received fluids during labor. Amniotomy was performed at $17.2 \%$ of deliveries. Oxytocin was administered in the 1 st and $2^{\text {nd }}$ periods of delivery at $14.6 \%$ of the cases (Table 2 ).

Less than half of the deliveries occurred in a non-lithotomic position $(39.7 \%)$ at the Centro Obstétrico Superior (COS) (Superior Obstetric

Table 1

Indicators at the Centro Obstétrico Superior (COS) (Superior Obstetric Center) and the Centro de Parto Normal (CPN) (Normal Delivery Center) at the Maternity in 2017. Teresina, Piauí, 2018.

\begin{tabular}{|c|c|c|c|c|c|c|}
\hline \multirow{2}{*}{$\begin{array}{l}\text { The WHO Recommendations } \\
2018\end{array}$} & \multirow{2}{*}{$\begin{array}{l}\text { Recommended: (Y) Yes } \\
\text { (N) No (SRC) Specific } \\
\text { Recommended Context }\end{array}$} & \multirow{2}{*}{$\begin{array}{l}\text { Indicators monitored at the } \\
\text { Maternity Hospital }\end{array}$} & \multicolumn{2}{|c|}{$\cos$} & \multicolumn{2}{|c|}{ CPN } \\
\hline & & & Total (n) & $(\%)^{*}$ & Total $(n)$ & $(\%)^{* *}$ \\
\hline \multirow[t]{2}{*}{-} & - & Deliveries in 2017 & 2,853 & 100.0 & 151 & 100.0 \\
\hline & & General care at childbirth & & & & \\
\hline 01 - Companion of choice & $\mathrm{Y}$ & Presence of companion or doula & 2,439 & 85.5 & 148 & 98.0 \\
\hline
\end{tabular}

* Percentage of the indicator, relative to the total number of deliveries performed at the COS from January to December 2017;

** Percentage of the indicator, relative to the total number of childbirths performed at the CPN from January to May 2017 . There are no indicators available from June to December 2017.

Source: Serviço de Arquivo Médico e Estatística (SAME) (Medical and Statistical Archive Service), 2018. 


\section{Table 2}

Indicators at the Centro Obstétrico Superior (COS) (Superior Obstetric Center) and the Centro de Parto Normal (CPN) (Normal Delivery Center) at the Maternity in 2017. Teresina, Piauí, 2018.

\begin{tabular}{|c|c|c|c|c|c|}
\hline The WHO Recommendations & Recommended: (Y) Yes & Indicators monitored at the & & & CPN \\
\hline 2018 & $\begin{array}{l}\text { (N) No (SRC) Specific } \\
\text { Recommended Context }\end{array}$ & Maternity Hospital & Total (n) & $(\%) *$ & Total $(\mathrm{n}) \quad(\%)^{* *}$ \\
\hline
\end{tabular}

\section{Care in the first period of childbirth}

01 - Cervical dilation rate of 01

$\mathrm{N}$

Childbirths accompanied by partogram

977

34.2

142

94.0

$\mathrm{cm} /$ hour during the first period.

04 - Early amniotomy in isolation to prevent prolonged labor.

05 - The use of synthetic oxytocin to prevent prolonged labor in women receiving epidural analgesia. Disruption

$$
\text { 2nd Period }
$$

Occurrence of Artificial Membrane

433

15.2

26

* Percentage of the indicator, relative to the total number of deliveries performed at the COS from January to December 2017; ** Percentage of the indicator, relative to the total number of births performed at the CPN from January to May 2017 . There are no indicators available from June to December 2017.

Source: Serviço de Arquivo Médico e Estatística (SAME) (Medical and Statistical Archive Service), 2018. 
Table 3

Indicators at the Centro Obstétrico Superior (COS) (Superior Obstetric Center) and the Centro de Parto Normal (CPN) (Normal Delivery Center) at the Maternity in 2017. Teresina, Piauí, 2018.

\begin{tabular}{|c|c|c|c|c|c|c|}
\hline \multirow{2}{*}{$\begin{array}{l}\text { The WHO Recommendations } \\
2018\end{array}$} & \multirow{2}{*}{$\begin{array}{l}\text { Recommended: (Y) Yes } \\
\text { (N) No (SRC) Specific } \\
\text { Recommended Context }\end{array}$} & \multirow{2}{*}{$\begin{array}{c}\text { Indicators monitored at the } \\
\text { Maternity Hospital }\end{array}$} & \multicolumn{2}{|c|}{$\cos$} & \multicolumn{2}{|c|}{ CPN } \\
\hline & & & Total (n) & $(\%) *$ & Total $(n)$ & $(\%)^{* *}$ \\
\hline \multicolumn{7}{|c|}{ Care in the second period of childbirth } \\
\hline $\begin{array}{l}01 \text { - For women without epidural } \\
\text { analgesia, encourage the free } \\
\text { choice of positions, including } \\
\text { vertical ones. }\end{array}$ & $\mathrm{Y}$ & Non-lithotomic childbirths & 1,132 & 39.7 & 141 & 93.4 \\
\hline $\begin{array}{l}02 \text { - Routine or common use of } \\
\text { episiotomy. }\end{array}$ & $\mathrm{N}$ & Episiotomy childbirths & 283 & 9.9 & 10 & 6.6 \\
\hline
\end{tabular}

* Percentage of the indicator, relative to the total number of deliveries performed at the COS from January to December 2017;

** Percentage of the indicator, relative to the total number of births performed at the CPN from January to May 2017 . There are no indicators available from June to December 2017.

Source: Serviço de Arquivo Médico e Estatística (SAME) (Medical and Statistical Archive Service), 2018.

Table 4

Indicators at the Centro Obstétrico Superior (COS) (Superior Obstetric Center) and the Centro de Parto Normal (CPN) (Normal Delivery Center) at the Maternity in 2017. Teresina, Piauí, 2018.

\begin{tabular}{|c|c|c|c|c|c|c|}
\hline \multirow{2}{*}{$\begin{array}{l}\text { The WHO Recommendations } \\
2018\end{array}$} & \multirow{2}{*}{$\begin{array}{l}\text { Recommended: (Y) Yes } \\
\text { (N) No (SRC) Specific } \\
\text { Recommended Context }\end{array}$} & \multirow{2}{*}{$\begin{array}{l}\text { Indicators monitored at the } \\
\text { Maternity Hospital }\end{array}$} & \multicolumn{2}{|c|}{$\cos$} & \multicolumn{2}{|c|}{ CPN } \\
\hline & & & Total (n) & $(\%) *$ & Total (n) & $(\%) * *$ \\
\hline \multicolumn{7}{|c|}{ Newborn Care } \\
\hline $\begin{array}{l}01 \text { - Skin to skin contact during } \\
\text { the first hour after birth, to pre- } \\
\text { vent hypothermia and promote } \\
\text { breastfeeding. }\end{array}$ & $\mathrm{Y}$ & $\begin{array}{l}\text { Newborn with immediate skin-to-skin } \\
\text { contact }\end{array}$ & 2,440 & 85.5 & 145 & 96.0 \\
\hline $\begin{array}{l}02 \text { - All newborns capable of } \\
\text { breastfeeding should be placed } \\
\text { on the breast as soon as possible. }\end{array}$ & $Y$ & $\begin{array}{c}\text { Newborn placed for breastfeeding in } \\
\text { the first hour }\end{array}$ & 1,868 & 65.5 & 142 & 94.0 \\
\hline
\end{tabular}

\footnotetext{
* Percentage of the indicator, relative to the total number of deliveries performed at the COS from January to December 2017 ;

** Percentage of the indicator, relative to the total number of births performed at the CPN from January to May 2017 . There are no indicators available from June to December 2017.

Source: Serviço de Arquivo Médico e Estatística (SAME) (Medical and Statistical Archive Service), 2018.
}

Center) and at the Centro de Parto Normal (CPN) (Normal Delivery Center), a non-lithotomic position was adopted at $93.4 \%$. At the Centro Obstétrico Superior (COS) (Superior Obstetric Center) and at the Centro de Parto Normal (CPN) (Normal Delivery Center) episiotomy was performed in $9.9 \%$ and $6.6 \%$ of the deliveries, respectively (Table 3 ).

During the first hour after birth, $85.5 \%$ of the newborns were placed in skin-to-skin contact with the mother, and, at $65.5 \%$, there was maternal breast- feeding promotion at the Centro Obstétrico Superior (COS) (Superior Obstetric Center). At the Centro de Parto Normal (CPN) (Normal Delivery Center) during the first hour after birth, $96 \%$ of the newborns were placed in skin-to-skin contact with the mother and $94 \%$ had maternal breastfeeding promotion (Table 4). 


\section{Discussion}

The WHO classifies its recommendations in practices that should or should not be adopted during each clinical period of childbirth and to the newborn. ${ }^{3}$ At the maternity in study, there is the monitoring of care indicators elaborated by the service team compiled in an Excel spreadsheet called "Childbirth Indicator Form", however, few are related to the WHO Recommendations that were updated in 2018.

In relation to general care in childbirth care, respectful maternity care, effective communication, the parturient's choice of companion and midwivery continuity care models are recommended. At the maternity, the presence of the parturient's choice of a companion was registered at $85.5 \%$ at the Centro Obstétrico Superior (COS) (Superior Obstetric Center) and $98 \%$ at the Centro de Parto Normal (CPN) (Normal Delivery Center) on childbirths. A national survey on the presence of a companion showed that $24.5 \%$ of the women had no companion at all, only $18.7 \%$ had continuous companionship and $56.8 \%$ had partial follow-up, values far below those found in this research, revealing the quality of care in this aspect. 15

In the first period of childbirth, the use of partogram was identified in the follow-ups on deliveries at $34.2 \%$ and $94 \%$ at the Centro Obstétrico Superior (COS) (Superior Obstetric Center) and at the Centro de Parto Normal (CPN) (Normal Delivery Center), respectively. Data from the "Nascer do Brasil" (Born in Brazil) research for the Northeast region 9 indicated that partogram monitoring occurred at $30.4 \%$ of the deliveries. A study conducted in Minas Gerais with 230 patients 16 demonstrated $77.4 \%$ on the use of partogram. This practice continues to be recommended by the WHO in 2018, as a sensitive instrument to monitor the evolution of childbirth, but without the criterion of 1 $\mathrm{cm} /$ hour dilation, the intervention is to be adopted. ${ }^{3}$

There is no scientific evidence to support the restriction of liquids and food during labor for the parturients at low risk of complications. ${ }^{9}$ For that matter, research data developed in the city of Recife indicated that $80 \%$ of the women ingested liquids during labor. 11 Moreover, this percentage was similar to that found in this study for the Centro Obstétrico Superior (COS) (Superior Obstetric Center) and the Centro de Parto Normal (CPN) (Normal Delivery Center) $(74.8 \%$ and $98.7 \%)$, which should continue to be encouraged if taken into account, for example, the energy expenditure required at labor.
The use of non-pharmacological technologies for pain relief identified in the research $(63.8 \%$ and $98 \%$ ) presented a percentage well above $19.1 \%$ identified in the study for the Northeast region, ${ }^{9}$ while it is similar to a study in the city of Belo Horizonte, 16 that indicated $74.2 \%$ of its use. These indexes can be considered as a positive aspect of the practices performed at the institution, showing a humanized care that promotes the parturient's well-being.

The acceleration of labor with amniotomy and/or oxytocin, plays an important role in the "cascade of interventions" and the reduction rate on spontaneous delivery. ${ }^{16}$ Data from a study conducted in the State of Goiás, ${ }^{17}$ containing a sample of 43 deliveries, described amniotomy at $16.3 \%$ of the deliveries, similar to that found in this study $(15.2 \%$ and $17.2 \%$ ), and the administration of oxytocin at $32.6 \%$, higher than the values found at the maternity in query $(26.5 \%$ and $14.6 \%)$, which monitors its use in the first and second periods of delivery.

In the second clinical period of delivery, there are indicators that monitor the number of deliveries in a non-lithotomic position and deliveries in which was episiotomy. Freedom of movement in the first phase of labor reduces working time, but does not seem to be associated with increased interventions or negative effects related to the mothers and newborns' well-being. In this study, less than half of the women (39.7\%) had deliveries in a non-lithotomic position at the Centro Obstétrico Superior (COS) (Superior Obstetric Center), while at the Centro de Parto Normal (CPN) (Normal Delivery Center) the percentage was $93.4 \%$. A nationwide study showed $91.7 \%$ of the deliveries in a lithotomic position for women at habitual risk and $91.8 \%$ for patients at non-habitual obstetric risk. ${ }^{9}$

In this research, episiotomy presented an adequate result being below the $10 \%$ recommended by the WHO at the two scenarios of this study, which may indicate that episiotomy is not a routine procedure performed, but selectively is. ${ }^{1}$ A percentage of $56.1 \%$ for women at habitual risk and $48.6 \%$ of women at non-habitual risk was described at a national level. 9

Interventions that are not recommended, such as the Kristeller Maneuver, continue to be described in $37.3 \%$ of the women with habitual risk vaginal delivery in Brazil. ${ }^{9}$ However, in the third period of childbirth, there are no indicators registered at the service that describe good practices or interventions performed.

Newborn care indicators demonstrate immediate uninterrupted skin-to-skin contact (85.5\% and 96\%) and breastfeeding at the first hour after birth $(65.5 \%$ 
and 94\%). A research conducted in the Sate of Minas Gerais 16 presents skin-to-skin contact in $60.5 \%$ and breastfeeding at the first hour after birth in only $25.5 \%$ of the deliveries. These variables presented better rates in both locations of this study, however, it is necessary to consider the great influence of institutional practices and the conditions of the newborn at birth both for early skin-to-skin contact and as for the beginning of breastfeeding in the delivery room. 18

After the delivery, care for women is not monitored by the indicators in any of the sectors, which has to be reviewed, as postpartum hemorrhage is the primary cause of almost a quarter of all maternal deaths worldwide and could be avoided by assessing the uterine atony and vaginal bleeding in the postpartum period. 19,20

The secondary data source stands out as one of the limitations in this study. Several indicators on the WHO recommendations did not exist and others were not registered, especially at the Centro de Parto Normal (CPN) (Normal Delivery Center) that did not report standardized indicators at the service from June to December, which refers to a reflection on how the assessment on care at the service occurs. However, the existence of a standardized spreadsheet with childbirth care indicators is positive, even if it was not possible to describe all clinical periods of delivery.

Although some indicators of this study presented to be adequate according to what the WHO proposes, the poor maternal and perinatal indicators in Brazil show the low quality of obstetric care at a national level. This fact emphasizes the importance of moni-

\section{References}

1. Carvalho EMP, Göttems LBD, Pires MRGM. Adesão às boas práticas de atenção ao parto normal: construção e validação de um instrumento. Rev Esc Enferm USP. 2015; 49 (6): 890-8.

2. OMS (Organização Mundial da Saúde). Assistência ao parto normal: um guia prático. Genebra; 1996

3. WHO (World Health Organization).WHO recommendations: intrapartum care for a positive childbirth experience. Geneva; 2018

4. Brasil. Ministério da Saúde. Programa de assistência integral à saúde da mulher. Brasília, DF; 1983.

5. Brasil. Ministério da Saúde. Programa de Humanização no Pré-Natal e Nascimento (PHPN). Brasília, DF; 2000

6. Brasil. Ministério da Saúde. Secretaria de Atenção à Saúde. Departamento de Ações Programáticas Estratégicas. toring the indicators on practices and non-recommended interventions, once, if they appear in the WHO guidelines it is because there are indications of their performance, confirmed by national and regional research spheres. $1,8-11,15-18$

This study allowed to comprehend the indicators on childbirth care present at the service and by analyzing them based on the WHO recommendations. It is expected to contribute to the services and professionals to understand the importance of registering the indicators and assessing childbirth care and their possible progress in the aspects that are necessary.

This study suggests an adequacy on the Childbirth Indicator Form currently used at the maternity, the research scenario, so that all aspects recommended and not recommended by the WHO in 2018 can be contemplated, as well as the elaboration of permanent education actions in order to discuss the importance of registrating and assessing care at a local level. Further studies are encouraged at the same scenario to analyze care compared to the 2017 data, as well as to analyze other services.

\section{Authors' contribution}

Resende MTS and Lopes DS contributed for the preparation and design of the study; the acquisition, analysis and interpretation of the data and the writing and/or revision of the manuscript; Bonfim EG contributed to the elaboration and design of the study and the writing and/or revision of the manuscript. All authors approved the final version of the article.
Política Nacional de Atenção Integral a Saúde da Mulher Princípios e Diretrizes. Brasília, DF; 2011.

7. Brasil. Ministério da Saúde. Secretaria da Saúde. Portaria $\mathrm{n}^{\circ} 1.1459$, de 24 de junho de 2011. Institui, no âmbito do Sistema Único de Saúde - SUS, a Rede Cegonha. DOU N ${ }^{\circ}$ 121, 27 junho 2011, Seção 1.

8. Medeiros RMK, Teixeira RC, Nicolini AB, Alvares AS, Corrêa ACP, Martins DP. Cuidados humanizados: a inserção de enfermeiras obstétricas em um hospital de ensino. Rev Bras Enferm. 2016; 69(6): 1029-36.

9. Leal MC, Pereira APE, Domingues RMSM, Theme Filha MM, Dias MAB, Nakamura-Pereira M, Bastos MH, Gama SGN. Intervenções obstétricas durante o trabalho de parto e parto em mulheres brasileiras de risco habitual. Cad Saúde Pública. 2014; 30 (Supl.): S17-S47. 
10. Fujita JALM, Shimo AKK. Parto humanizado: experiências no sistema único de saúde. Rev Min Enferm. 2014; 18 (4) 1006-10.

11. Andrade PON, Silva JQP, Diniz CMM, Caminha MFC. Fatores associados à violência obstétrica na assistência ao parto vaginal em uma maternidade de alta complexidade em Recife, Pernambuco. Rev Bras Saúde Mater Infant. 2016; 16(1): 29-37.

12. Organização Pan-Americana da Saúde. REDE Interagencial de Informação para a Saúde Indicadores básicos para a saúde no Brasil: conceitos e aplicações. Rede Interagencial de Informação para a Saúde - Ripsa. 2 ed. Brasília, DF; 2008.

13. Reis ZSN, Pereira AC, Correia RJC, Freitas JAS, Cabral ACV, Bernardes J. Análise de indicadores da saúde materno-infantil: paralelos entre Portugal e Brasil. Rev Bras Ginecol Obstet. 2011; 33(9): 234-9.

14. Brasil. Conselho Nacional de Saúde. Resolução n ${ }^{\circ} 466$ de 12 de dezembro de 2012. Trata de pesquisas em seres humanos. DOU, 13 junho de 2013.

15. Diniz CSG, d'Orsi E, Domingues RMSM, Torres JA, Dias MAB, Schneck CA, Lansky S, Teixeira NZF, Rance S, Sandall J. Implementação da presença de acompanhantes durante a internação para o parto: dados da pesquisa nacional Nascer no Brasil. Cad Saúde Pública. 2014; 30 (Suppl.1): S140-S153.

Received on March 19, 2019

Final version presented on April 1, 2020

Approved on May 6, 2020
16. Sousa AMM, Souza KV, Rezende EM, Martins EF, Campos D, Lansky S. Práticas na assistência ao parto em maternidades com inserção de enfermeiras obstétricas, em Belo Horizonte, Minas Gerais. Esc Anna Nery. 2016; 20(2): 32431 .

17. Oliveira NRG, Assis TR, Amaral WN, Falone VE, Salviano LMO. Assistance to Normal Delivery in Two Public Maternities: Perception of the Health Professionals. Rev Bras Ginecol Obstet. 2017; 39(5): 202-8.

18. Silva CM, Pereira SCL, Passos IR, Santos LC. Fatores associados ao contato pele a pele entre mãe/filho e amamentação na sala de parto. Rev Nutr. 2016; 29(4): 45771.

19. OMS (Organização Mundial da Saúde). Recomendações da OMS para a prevenção e tratamento da hemorragia pósparto. Genebra; 2014.

20. Periard AM, Rezende BM, Viegas Segundo E, Cosso FMG, Lopes JRB, França MA, Silva RMP, Valadares RFLA, Lima SA, Corrêa Junior MD. Atonia uterina e hemorragia pósparto. Rev Med Minas Gerais. 2011; 21(4Supl. 6): S1-S143. 